\title{
Characterization of $\beta_{2}$ (CD18) integrin phosphorylation in phorbol ester-activated T lymphocytes
}

\author{
Leena VALMU*, Tiina J. HILDEN*, Gijsbert van WILLIGEN $\dagger$ and Carl G. GAHMBERG*1 \\ *Department of Biosciences, Division of Biochemistry, P.0. Box 56 (Viikinkaari 5), 00014 University of Helsinki, Finland, and †Department of Haematology, \\ University Hospital Utrecht, P.0. Box 85.500, 3508 GA Utrecht, The Netherlands
}

\begin{abstract}
Integrins are transmembrane proteins involved in cell-cell and cell-extracellular-matrix interactions. The affinity and avidity of integrins for their ligands change in response to cytoplasmic signals. This 'inside-out' activation has been reported to occur also with $\beta_{2}$ integrins (CD18). The $\beta_{2}$ integrin subunit has previously been shown to become phosphorylated in T lymphocytes on cytoplasmic serine and the functionally important threonine residues after treatment with phorbol esters or on triggering of $\mathrm{T}$-cell receptors. We have now characterized the phosphorylation of $\beta_{2}$ integrins in T-cells in more detail. When T-cells were activated by phorbol esters the phosphorylation
\end{abstract}

was mainly on $\mathrm{Ser}^{756}$. After inhibition of serine/threonine phosphatases, phosphorylation was also found in two of the threonine residues in the threonine triplet 758-760 of the $\beta_{2}$ cytoplasmic domain. Activation of T-cells by phorbol esters resulted in phosphorylation in only approx. $10 \%$ of the integrin molecules. Okadaic acid increased this phosphorylation to approx. $30 \%$ of the $\beta_{2}$ molecules, assuming three phosphorylation sites. This indicates that a strong dynamic phosphorylation exists in serine and threonine residues of the $\beta_{2}$ integrins.

Key words: adhesion, phosphatases, protein kinases.

\section{INTRODUCTION}

Integrins are transmembrane proteins that form a superfamily of proteins involved in regulated cell-cell and cell-substratum interactions [1]. They have a prominent role in the attachment and detachment of cells to/from their surrounding matrix and in a number of different adhesion events in the immune system. All integrins discovered so far are heterodimers consisting of $\alpha$ and $\beta$ subunits. The family was originally characterized by structurally related $\beta$ subunits that formed a series of heterodimers with distinct $\alpha$ subunits. However, more recent findings indicate that there are several important exceptions to this concept.

The affinity or avidity of integrins for their extracellular ligands can change in response to cytoplasmic signals initiated by the stimulation of cellular receptors [2,3]. This 'activation' of integrins has been termed 'inside-out' signalling [4,5]. Several integrin families have been shown to undergo activation, such as the $\beta_{3}$-integrins in platelets [4], the $\beta_{2}$-integrins in leucocytes [3] and the $\beta_{1}$-integrins in haemopoietic cells [6]. In addition to the affinity modulation the integrins also activate intracellular signalling pathways in a process termed 'outside-in' signalling [7]. These signals produced by engagement of integrins include the generation of lipid second messengers, the activation of protein kinases, phosphoinositide kinases and small GTP-binding proteins and changes in intracellular $\mathrm{pH}$ and $\left[\mathrm{Ca}^{2+}\right]$.

Integrin $\beta$ subunit cytoplasmic domains have a central role both in 'inside-out' and 'outside-in' signal transduction [8]. The cytoplasmic domain sequences are highly conserved between species, which suggests an indispensable role for these portions of the polypeptides. A number of elements in the cytoplasmic domains of integrin $\beta$ subunits have been shown to be important both in the regulation of integrin activity [5] and in the signal transduction mediated by integrins [8]. These include the membrane-proximal elements in the $\beta_{1}$ and $\beta_{3}$ polypeptides whose deletion leads to a constitutively active phenotype [9]. The cytoplasmic portions contain binding sites for cytoskeletal proteins such as $\alpha$-actinin [10], talin [11] and paxillin [12] and for regulatory proteins such as $\beta_{3}$-endonexin [13]. Particularly important are the Asn-Pro-Xaa-Tyr regions implicated in the activation of $\beta_{1}$ and $\beta_{3}$ integrins [14] and the Thr-Thr-Thr triplet necessary for the adhesion mediated by $\beta_{2}$ integrins [15].

The cytoplasmic domains of the integrin $\beta$ subunits contain a number of putative phosphorylation sites. Because integrin phosphorylation might be a mechanism by which both integrin activation and signal transduction could be regulated, the phosphorylation status of integrins has been extensively studied. $\beta_{1}$ integrin [16] and $\beta_{3}$ integrin [17,18] have been shown to become phosphorylated on tyrosine residues; this tyrosine phosphorylation is likely to take place in their conserved AsnPro-Xaa-Tyr motifs. In addition, the $\beta_{4}$ integrin subunit has been shown to become tyrosine-phosphorylated [19]. These tyrosine phosphorylation events are generally induced by cell adhesion and are thus believed to mediate 'outside-in' signal transduction by integrins.

Phorbol esters, potent activators of protein kinase $\mathrm{C}$, have been found to induce $\beta_{2}$ integrin activation in leucocytes [20,21] as well as $\beta_{1}$ integrin activation of haemopoietic cells [6]. The integrin $\alpha_{\mathrm{II}} \beta_{3}$, which can normally be stimulated by agonists such as thrombin or platelet-activating factor in platelets [4], can also be activated by phorbol esters [22]. These findings led to speculation on the involvement of serine/threonine phosphorylation in the 'inside-out' signalling of integrins. In $\beta_{3}$ the phosphorylation was shown to occur on threonine residues only after stimulation by thrombin or phorbol ester [23].

Abbreviations used: FCS, fetal calf serum; PDBu, phorbol 12,13-dibutyrate; TCR, T-cell receptor.

1 To whom correspondence should be addressed (e-mail carl.gahmberg@helsinki.fi). 
The $\beta_{2}(\mathrm{CD} 11 / \mathrm{CD} 18)$ integrins comprise a family of leucocyte integrins with four distinct $\alpha$ chains $\left(\alpha_{\mathrm{L}}\right.$ or CD11a, $\alpha_{\mathrm{M}}$ or CD $11 \mathrm{~b}$, $\alpha_{\mathrm{X}}$ or CD11c and $\alpha_{\mathrm{D}}$ or CD11d) [24]. They are expressed solely on leucocytes and are of pivotal importance in leucocyte adhesion. The activation of $\beta_{2}$ integrin can be triggered artificially by phorbol esters $[20,21]$, and with antibodies directed against $\beta_{2}$ integrins $[25,26]$ or other leucocyte surface proteins such as the T-cell receptor (TCR) complex [27]. The mechanism by which this 'inside-out' activation is mediated is poorly understood. The phosphorylation of leucocyte integrins has been studied extensively and the phosphorylation state of $\beta_{2}$ integrins has been reported to change in phorbol ester-activated leucocytes [28-31]. The $\alpha$ chains were shown to be constitutively phosphorylated, whereas the $\beta_{2}$ chain was reported to become phosphorylated only after treatment with phorbol ester. The induced phosphorylation of $\beta_{2}$ occurred almost exclusively on serine [29,31], and in the study where the putative phosphorylation sites of $\beta_{2}$ were mutated, the major phosphorylation site was identified as $\operatorname{Ser}^{756}$ in the $\beta_{2}$ cytoplasmic domain [15]. Although activation by phorbol esters revealed only serine phosphorylation in $\beta_{2}$ under these experimental conditions, it has become evident that the activation also induces a dynamic threonine phosphorylation in $\beta_{2}$, which can be revealed only when serine/threonine phosphatases in T-cells are inhibited by okadaic acid [32].

The amino acids on which the rapid phosphorylation/dephosphorylation of $\beta_{2}$ takes place are not known, but the only threonine residues present in the $\beta_{2}$ cytoplasmic domain exist in the threonine triplet (758-760) shown to be vital for the activation of the integrin [15]. We therefore considered it important to map the dynamic phosphorylation sites in $\beta_{2}$.

\section{EXPERIMENTAL}

\section{Materials}

RPMI 1640, L-glutamine and penicillin/streptomycin were purchased from Hyclone Europe Ltd (Cramlington, Northumberland, U.K.). Fetal calf serum (FCS) was obtained from Biological Industries (Kibbutz Bet HaEmak, Israel). Phosphate-free minimal essential medium, PMSF, aprotinin, leupeptin, iodoacetamide, quercetin, tosyl-lysylchloromethane ('TLCK'), tosylphenylalanylchloromethane ('TPCK'), $\mathrm{N}$ benzyloxycarbonyl-L-phenylalanine chloromethyl ketone, polyvinylpyrrolidone and glucose were purchased from Sigma Chemical Co. (St. Louis, MO, U.S.A.). ATP, ADP, AMP, GTP and GDP were obtained from Boehringer Mannheim (Mannheim, Germany) and an ATP-monitoring reagent from BioOrbit (Turku, Finland). Ninhydrin was obtained from Merck (Darmstadt, Germany). Protein G-Sepharose and FicollHypaque were from Pharmacia Biotech (Uppsala, Sweden). Sequencing-grade modified trypsin (activity more than 2.5 units $/ \mathrm{mg}$ ) was purchased from Promega (Madison, WI, U.S.A.) and hexokinase (1500 units $/ \mathrm{ml})$ from Boehringer Mannheim. Phorbol 12,13-dibutyrate (PDBu) (Sigma) and okadaic acid (Calbiochem-Novabiochem Co., La Jolla, CA, U.S.A.) were dissolved in DMSO. $\left[{ }^{32} \mathrm{P}\right] \mathrm{P}_{\mathrm{i}}$ (aqueous solution; $10 \mathrm{mCi} / \mathrm{ml}, 5000 \mathrm{Ci} / \mathrm{mmol}$ ) was purchased from the Radiochemical Centre (Amersham, Little Chalfont, Bucks., U.K.). The monoclonal antibody R7E4 against the $\beta_{2}$ subunit of leucocyte integrins has been described previously [33].

\section{Synthesis of peptides}

Synthetic peptides were synthesized by solid-phase synthesis using 9-fluorenylmethoxycarbonyl chemistry in an Applied Biosystems model 433A automatic peptide synthesizer. Amino acids were activated by using the 2-(1- $H$-benzotiazol-1-yl)-1,1,3,3tetramethyluronium hexafluorophosphate/1-hydroxybenzotriazole method. Peptides were purified by HPLC with a $\mathrm{C}_{18}$ reverse-phase column (Bondapack; Waters) and the sequences were confirmed by matrix-assisted laser desorption ionizationtime-of-flight MS mass analysis. The following $\beta_{2}$ cytoplasmic phosphopeptides were synthesized: 24-residue peptides (residues 746-769) with either $\operatorname{Ser}^{756}$ (S ${ }^{756}$-peptide), $\operatorname{Ser}^{756}$ and $\mathrm{Thr}^{758}$ (S ${ }^{756} \mathrm{~T}$-peptide), $\mathrm{Ser}^{756}$ and $\mathrm{Thr}^{758}-\mathrm{Thr}^{759}$ ( $\mathrm{S}^{756} \mathrm{~T} 2$-peptide) or $\mathrm{Ser}^{756}$ and $\mathrm{Thr}^{758}$ - $\mathrm{Thr}^{759}$ - $\mathrm{Thr}^{760}$ (S $\mathrm{S}^{756} \mathrm{~T} 3$-peptide) phosphorylated, a nine-residue peptide (residues $725-733)$ with $\operatorname{Ser}^{730}\left(\mathrm{~S}^{730}\right.$ peptide) phosphorylated, an 11-residue peptide (residues 745 755) with $\operatorname{Ser}^{745}$ phosphorylated ( $\mathrm{S}^{745}$-peptide) and a 4-residue peptide otherwise corresponding to residues 766-769 except Glu $^{768}$ and phosphorylated Ser ${ }^{769}$ switched ( $\mathrm{S}^{769}$-peptide), because the synthesis was more easily accomplished when the phosphorylated serine residue was not at the C-terminus.

\section{T-cell isolation}

Buffy coats used for the isolation of T-cells were obtained from the Finnish Red Cross Blood Transfusion Service (Helsinki, Finland). Mononuclear leucocytes were isolated by FicollHypaque gradient centrifugation. T-cells were further enriched by using nylon-wool columns. Enriched T-cells were either subjected to radiolabelling with ${ }^{32} \mathrm{P}$ or suspended in RPMI 1640 medium supplemented with $10 \%$ (v/v) FCS, $1 \%(\mathrm{w} / \mathrm{v})$ Lglutamine and antibiotics and $10 \mathrm{mM}$ Hepes and left in culture overnight at $37^{\circ} \mathrm{C}$.

\section{Radiolabelling with ${ }^{32} \mathrm{P}$ and cell activation}

Enriched T-cells were washed with phosphate-free minimal essential medium supplemented with $5 \%(\mathrm{v} / \mathrm{v})$ dialysed FCS, $10 \mathrm{mM}$ Hepes, $1 \%$ L-glutamine and antibiotics, then suspended in the same medium to a density of $50 \times 10^{6}$ cells $/ \mathrm{ml}$. After preincubation for $1 \mathrm{~h}$ at $37{ }^{\circ} \mathrm{C}, 1-2 \mathrm{mCi}$ of $\left[{ }^{32} \mathrm{P}\right] \mathrm{P}_{\mathrm{i}}$ was added. Cells were labelled either overnight at $37{ }^{\circ} \mathrm{C}$ or for different durations as indicated.

The cells were preincubated with $1.5 \mu \mathrm{M}$ okadaic acid for $25 \mathrm{~min}$ and subsequently activated with $200 \mathrm{nM} \mathrm{PDBu}$ for $30 \mathrm{~min}$ at $37^{\circ} \mathrm{C}$. The activation was stopped by the addition of ice-cold $10 \mathrm{mM}$ EDTA/PBS, and the cells were washed once with icecold $2 \mathrm{mM}$ EDTA/PBS. The cells were lysed at $0{ }^{\circ} \mathrm{C}$ for $15 \mathrm{~min}$ in $1 \%(\mathrm{v} / \mathrm{v})$ Triton $\mathrm{X}-100 / 10 \mathrm{mM}$ sodium phosphate $/ 10 \mathrm{mM}$ sodium pyrophosphate $/ 50 \mathrm{mM}$ sodium fluoride $/ 1 \mathrm{mM}$ sodium orthovanadate $/ 10 \mathrm{mM}$ EDTA/350 mM NaCl/1 mM PMSF/ $10 \mu \mathrm{g} / \mathrm{ml}$ aprotinin $/ 10 \mu \mathrm{g} / \mathrm{ml}$ leupeptin $/ 5 \mathrm{mM}$ iodoacetamide/ $0.1 \mathrm{mM}$ quercetin $/ 0.1 \mathrm{mM}$ tosyl-lysylchloromethane $/ 0.1 \mathrm{mM}$ tosylphenylalanylchloromethane $/ 0.1 \mathrm{mM} N$-benzyloxycarbonylL-phenylalanine chloromethylketone (pH 7.4). Cell lysates were centrifuged at $60000 \mathrm{~g}$ for $30 \mathrm{~min}$ at $2{ }^{\circ} \mathrm{C}$ and the supernatants were used either for immunoprecipitation or for the extraction of nucleotides with 1 vol. of EDTA/ethanol [10 mM EDTA in $86 \%(\mathrm{v} / \mathrm{v})$ ethanol, $\mathrm{pH} 7.4]$.

\section{Immunoprecipitation}

Cell lysates were precleared with Protein G-Sepharose for $1 \mathrm{~h}$ at $4{ }^{\circ} \mathrm{C}$; the $\beta_{2}$ integrin complexes were then immunoprecipitated with monoclonal antibody R7E4 covalently coupled [34] to Protein G-Sepharose. After incubation for $2.5 \mathrm{~h}$ at $4{ }^{\circ} \mathrm{C}$ with constant rolling, Sepharose beads were washed eight times with decreasing detergent and salt concentrations. Bound proteins were eluted with $1 \%(\mathrm{w} / \mathrm{v}) \mathrm{SDS}$ at $40{ }^{\circ} \mathrm{C}$ for $40 \mathrm{~min}$ and then subjected to SDS/PAGE. 


\section{SDS/PAGE and silver staining}

SDS/PAGE $[8 \%(\mathrm{w} / \mathrm{v})$ gel] was performed by the method of Laemmli [35]. For phosphopeptide mapping the samples were alkylated with $10 \mathrm{mM}$ dithiothreitol/3 mM EDTA, and $20 \mathrm{mM}$ iodoacetamide was added for $15 \mathrm{~min}$ at room temperature before SDS/PAGE.

Electrophoresed proteins were sometimes revealed by staining with silver. The gel was fixed in $30 \%(\mathrm{v} / \mathrm{v})$ ethanol $/ 0.5 \%(\mathrm{v} / \mathrm{v})$ acetic acid for $1 \mathrm{~h}$. After being washed, the gel was sensitized with $0.02 \%$ sodium thiosulphate for $1 \mathrm{~min}$. The gel was rinsed, incubated with $0.2 \%$ silver nitrate for $30 \mathrm{~min}$ and developed in $37 \%(\mathrm{v} / \mathrm{v})$ formaldehyde $/ 3 \%(\mathrm{v} / \mathrm{v})$ potassium carbonate/ $0.001 \%$ sodium thiosulphate.

\section{Phosphopeptide mapping}

For phosphopeptide mapping, ${ }^{32} \mathrm{P}$-labelled proteins were resolved by SDS/PAGE, blotted on PVDF membranes (Millipore, Bedford, MA, U.S.A.), located with a Fuji BAS 1000 PhosphoImager (Tokyo, Japan) and the regions corresponding to $\beta_{2}$ were excised. The filter pieces were first saturated with polyvinylpyrrolidone 360 at $37^{\circ} \mathrm{C}$ for $1 \mathrm{~h}$; after being washed, the protein was digested with trypsin at $37^{\circ} \mathrm{C}$ overnight. The resulting peptides were separated in the first dimension by electrophoresis at $\mathrm{pH} 8.0$ by using the HTLE-7000 electrophoresis system (C.B.S. Scientific company, Del Mar, CA, U.S.A.) and in the second dimension by ascending chromatography [36]. ${ }^{32} \mathrm{P}$-labelled peptides were detected and quantified by PhosphoImager analysis; synthetic peptides were revealed by ninhydrin staining.

\section{Separation, identification and quantitation of nucleotides}

${ }^{32} \mathrm{P}$-labelled nucleotides and metabolites were separated by either TLC on $20 \mathrm{~cm} \times 20 \mathrm{~cm}$ PEI-Cellulose $F$ sheets (Merck, Darmstadt, Germany) with $1.2 \mathrm{M}$ ammonium formate $/ 0.8 \mathrm{M}$ $\mathrm{HCl}$ or by two-dimensional paper chromatography on Whatman No. 1 paper as described [37]. The identities of the spots were verified with unlabelled standard ATP, ADP, AMP, GTP and GDP, which were detected by measuring $A_{254}$. The radioactivities in the spots were determined by liquid-scintillation counting (Wallac, Turku, Finland)

The amount of ${ }^{32} \mathrm{P}$ in the $\gamma$-phospho group of ATP was quantified by incubation of the T-cell lysates with $2 \mathrm{mM}$ $\mathrm{MgCl}_{2} / 2 \mathrm{mM}$ glucose/1 unit of hexokinase for $10 \mathrm{~min}$ at $37^{\circ} \mathrm{C}$, followed by $4 \mathrm{~min}$ in boiling water. Precipitated enzymes were centrifuged and the nucleotides were extracted and separated as described above.

\section{Determination of the stoichiometry of phosphorylation}

The stoichiometry of the phosphorylation of the $\beta_{2}$ subunit was analysed essentially as described [38], and calculated by comparing the incorporation of ${ }^{32} \mathrm{P}$ into $\beta_{2}$ from the $\gamma$-phospho group of $\left[{ }^{32} \mathrm{P}\right] \mathrm{ATP}$; the amount of $\beta_{2}$ was measured by densitometry. In brief, T-cells were labelled with $\left[{ }^{32} \mathrm{P}\right] \mathrm{P}_{\mathrm{i}}$ overnight, then activated and lysed as described. Adenine nucleotides in lysate were extracted and the ${ }^{32} \mathrm{P}$ incorporated into ATP was determined by liquid-scintillation counting after TLC. The absolute amount of ATP in lysates was measured by the luciferin/luciferase technique with an LKB Wallac 1250 luminometer (Turku, Finland) [39]. The ${ }^{32} \mathrm{P}$ incorporated into $\beta_{2}$ was determined after the integrin complexes had been immunoprecipitated and subjected to SDS/PAGE. Gels were stained with silver and the absolute amount of $\beta_{2}$ subunit was determined by densitometric comparison with serial dilutions of purified $\beta_{2}$ molecules. For determination of the ${ }^{32} \mathrm{P}$ radioactivity in $\beta_{2}$ the specific area was cut out of the dried gels and heated for $1 \mathrm{~h}$ at $80{ }^{\circ} \mathrm{C}$ in $30 \%$ (v/v) $\mathrm{H}_{2} \mathrm{O}_{2}$. The radioactivity was determined by liquid-scintillation counting.

\section{RESULTS}

\section{Identification of the phosphorylation sites in the $\beta_{2}$ integrin subunit in phorbol ester-activated T-cells}

Because the $\beta_{2}$ integrin subunit has previously been shown to become phosphorylated in phorbol ester-induced leucocytes both in a stable manner on a serine residue [15] and more dynamically on threonine residues [32], it was important to map the dynamic phosphorylation sites of $\beta_{2}$. Tryptic phosphopeptide maps were made from ${ }^{32} \mathrm{P}$-labelled T-cells (Figure 1) treated either with $\mathrm{PDBu}$ alone or with $\mathrm{PDBu}$ after pretreatment with okadaic acid. PDBu induced $\beta_{2}$ phosphorylation (Figure 1A), which was markedly augmented by preincubation with okadaic acid (Figure 1C). Okadaic acid alone did not induce $\beta_{2}$ phosphorylation (results not shown), as reported previously [32]. The phosphorylated $\beta_{2}$ was isolated and digested further with trypsin; the phosphopeptides produced were separated on cellulose plates (Figures 1B, 1D and 1E). Tryptic peptides digested from synthetic phosphopeptides comprising the last 24 residues at the $\mathrm{C}$ terminus of the $\beta_{2}$ cytoplasmic tail with phosphate in either $\operatorname{Ser}^{756}$ or in different threonine residues 758-760 were added as markers (Figure 2).

In a phosphopeptide map of $\beta_{2}$ produced from PDBu-activated T-cells (Figure 1B) a spot was detected that migrated identically with the synthetic peptide having a single phosphorylation site on $\mathrm{Ser}^{756}$, the $\mathrm{S}^{756}$-peptide (indicated by $\mathrm{S}$ ). Because it has been demonstrated previously that phosphorylation occurs only in

A

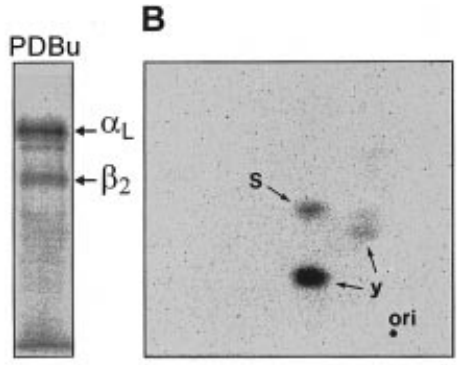

c

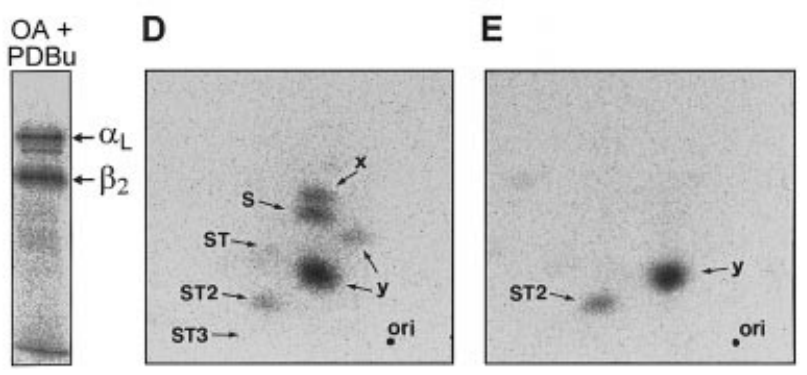

Figure 1 Tryptic phosphopeptides of the $\boldsymbol{\beta}_{2}$ polypeptide

$\beta_{2}$ integrins were immunoprecipitated and subjected to SDS/PAGE from ${ }^{32} \mathrm{P}$-labelled T-cells activated with either PDBu alone $(\mathbf{A})$ or with PDBu after pretreatment with okadaic acid $(\mathbf{C})$. $\beta_{2}$ was further digested with trypsin. The tryptic $\beta_{2}$ peptides obtained from T-cells with activation by PDBu alone $(\mathbf{B})$ or with treatment with okadaic acid and PDBu together $(\mathbf{D}, \mathbf{E})$ were run on cellulose plates together with synthetic phosphopeptides (see Figure 2) also digested with trypsin. The experiments were repeated eight times with essentially similar results. 


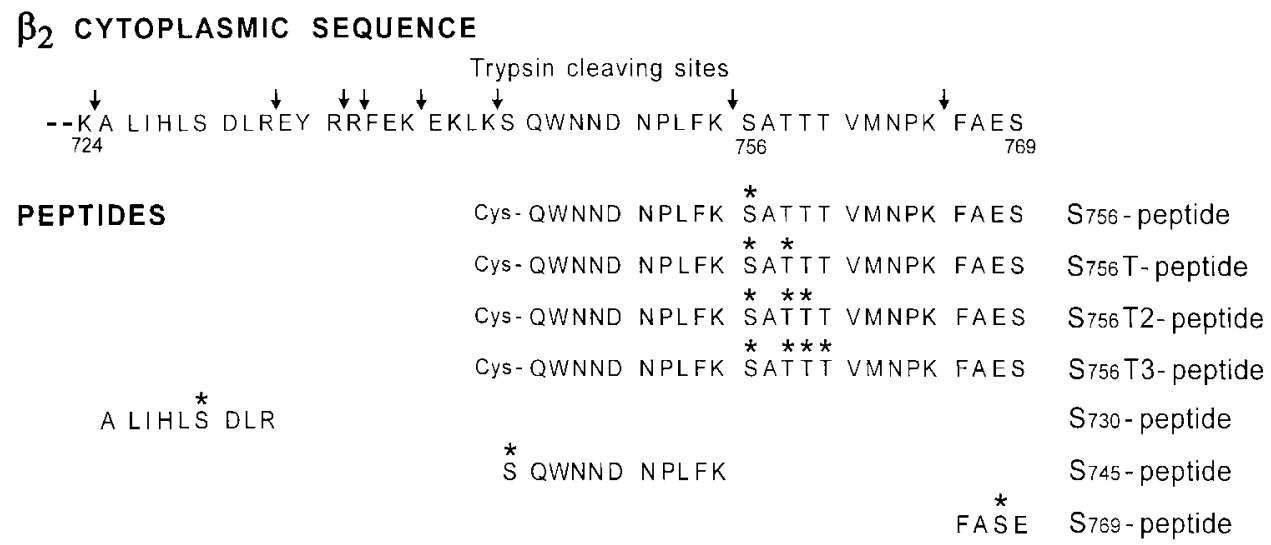

\section{Figure 2 Synthetic phosphopeptides of $\beta_{2}$ used in the study}

The synthetic phosphopeptides corresponding to the amino acid sequence of the $\beta_{2}$ cytoplasmic domain are shown (single-letter codes). The positions of the phosphorylated amino acids are indicated with asterisks.

$\operatorname{Ser}^{756}$ after activation by phorbol ester [15], the extra spots seen in the phosphopeptide map (indicated by y) are most likely to represent peptides produced by incomplete digestion with trypsin. The incomplete digestion is probably due to the phosphate group in $\mathrm{Ser}^{756}$, which interferes with the trypsin cleavage at Lys ${ }^{755}$. The incomplete digestion was confirmed by using matrix-assisted laser desorption ionization-time-of-flight MS mass analysis with the synthetic peptides (results not shown) as well as by phosphopeptide maps of trypsin-digested synthetic peptides, in which the major incompletely cleaved spot also was seen. Furthermore, when the synthetic phosphopeptides were run on cellulose plates without previously being digested with trypsin, the spot corresponding to the complete peptide migrated identically with the spot corresponding to the uncleaved peptides in the phosphopeptide map (indicated by y). Quantification of the ${ }^{32} \mathrm{P}$ incorporated into peptide spots revealed $84.2 \pm 4.0 \%$ of the total radioactivity in the spots representing the incompletely digested peptides, and $15.8 \pm 3.9 \%$ in the spot corresponding to the $\mathrm{S}^{756}$ peptide.

After the activation of T-cells by PDBu after the inhibition of serine/threonine phosphatases by okadaic acid, different phosphopeptide maps were produced (Figures 1D and 1E). In some experiments (Figure 1D), as after PDBu activation alone, a spot was detected that corresponded to the synthetic peptide with a single phosphorylation site at $\operatorname{Ser}^{756}$, the $\mathrm{S}^{756}$ peptide (indicated by $\mathrm{S}$ ) $; 14.7 \pm 6.6 \%$ of the total ${ }^{32} \mathrm{P}$ was incorporated in the spot. A spot that co-migrated with the synthetic peptide $\mathrm{S}^{756} \mathrm{~T} 2$ with phosphates on $\mathrm{Ser}^{756}$ and on $\mathrm{Thr}^{758}$ and $\mathrm{Thr}^{759}$ was also clearly detected (indicated by ST2) containing $6.8 \pm 0.4 \%$ of the total radioactivity incorporated. In contrast, a spot corresponding to the $\mathrm{S}^{756} \mathrm{~T}$-peptide with $\mathrm{Ser}^{756}$ and only $\mathrm{Thr}^{758}$ phosphorylated (indicated by ST) was hardly detectable, with only $2.1 \pm 1.9 \%$ of the total radioactivity, and no radioactive spot could be seen in the position where the synthetic $\mathrm{S}^{756} \mathrm{~T} 3-$ peptide migrated with $\mathrm{Ser}^{756}, \mathrm{Thr}^{758}$, $\mathrm{Thr}^{759}$ and $\mathrm{Thr}^{760}$ phosphorylated (indicated by ST3). An extra spot (indicated by $\mathrm{x})$ was also produced in the cells treated with okadaic acid and $\mathrm{PDBu}$, with $8.0 \pm 2.1 \%$ of the total radioactivity incorporated. The possibility of novel phosphorylation sites in the $\beta_{2}$ integrin subunit was further tested by $\beta_{2}$ tryptic phosphopeptide maps run together with synthetic phosphopeptides corresponding to tryptic peptides of the $\beta_{2}$ cytoplasmic domain with all the other putative phosphorylation sites in $\operatorname{Ser}^{730}$ ( $\mathrm{S}^{730}$-peptide), $\mathrm{Ser}^{745}$
( $\mathrm{S}^{745}$-peptide) and $\mathrm{Ser}^{769}$ (S-peptide) phosphorylated (see Figure 2 ). None of the synthetic peptides tested co-migrated with the extra spot $(\mathrm{x})$ in the phosphopeptide map produced from ${ }^{32} \mathrm{P}$ labelled $\beta_{2}$. Because the extra spot migrates very close to the peptide containing a single phosphorylation site at $\operatorname{Ser}^{756}$ and because the spot could not be seen in all experiments, it is likely to be a modification of the same $\mathrm{Ser}^{756}$-phosphorylated peptide. One possible modification is the oxidation of $\mathrm{Met}^{762}$. Incompletely digested peptides were again detected (indicated by y) in the phosphopeptide map at the same location as in the map of PDBu-activated cells alone; the amount of radioactivity in this spot was $68.4 \pm 12.2 \%$ of the total ${ }^{32} \mathrm{P}$.

In approximately half of the experiments with T-cells pretreated with okadaic acid and activated by $\mathrm{PDBu}$ a different phosphopeptide map of ${ }^{32} \mathrm{P}$-labelled tryptic peptides of $\beta_{2}$ was produced (Figure 1E): a single spot was detected that migrated together with a synthetic $\mathrm{S}^{756} \mathrm{~T} 2$-peptide in addition to the incompletely digested peptides (indicated by y). The radioactivity in the uncleaved peptide spot was $85.0 \pm 1.6 \%$ of the total ${ }^{32} \mathrm{P}$ incorporated into $\beta_{2} ; 15.0 \pm 1.6 \%$ of the radioactivity was found in the spot corresponding to the $\mathrm{S}^{756} \mathrm{~T} 2$-peptide. No peptides were observed in the positions corresponding to the $S^{756}$-peptide or the $\mathrm{S}^{756} \mathrm{~T}$-peptide. The difference between these two phosphopeptide maps is most probably due to variability in okadaic acid batches between experiments. Okadaic acid is not always capable of inhibiting phosphatases in a repeatable and complete manner. The phosphopeptide map shown in Figure 1(D) was probably the result of incomplete inhibition by okadaic acid, thus resulting in molecules with only Ser ${ }^{756}$ phoshorylated, both $\operatorname{Ser}^{756}$ and one threonine residue phosphorylated, and molecules with $\operatorname{Ser}^{756}$ and two threonine residues phosphorylated. In some experiments the inhibition by okadaic acid was more complete, however, and the phosphopeptide map produced was as shown in Figure 1(E), in which only the molecule with $\operatorname{Ser}^{756}$ and two of the threonine residues phosphorylated was produced.

A further effort was made to find out which threonine residues were phosphorylated in T-cells treated with okadaic acid and PDBu. The precursor-ion-scan method selective for phosphorylated peptides [40] with an ESI mass spectrometer was used, as well as a manual sequencing method for the identification of phosphorylated amino acids [41]; however, neither of the methods was sensitive enough for identification of the threonine phosphorylation sites in $\beta_{2}$ integrin. 
A

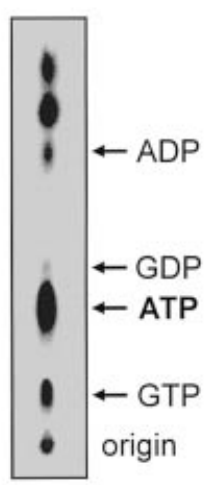

B

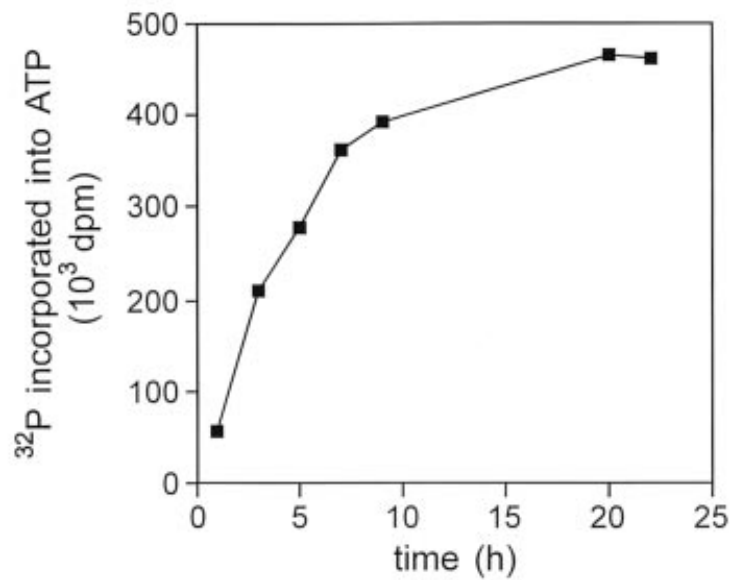

Figure 3 Saturation of ATP labelling with ${ }^{32} \mathrm{P}$ with time

T-cells were radiolabelled with ${ }^{32} \mathrm{P}$ for the indicated durations and after lysis the nucleotides were extracted. ${ }^{32} \mathrm{P}$-labelled nucleotides were separated by TLC (A) and the radioactivities incorporated into ATP were determined $(\mathbf{B})$. The results are representative of two separate experiments.

A
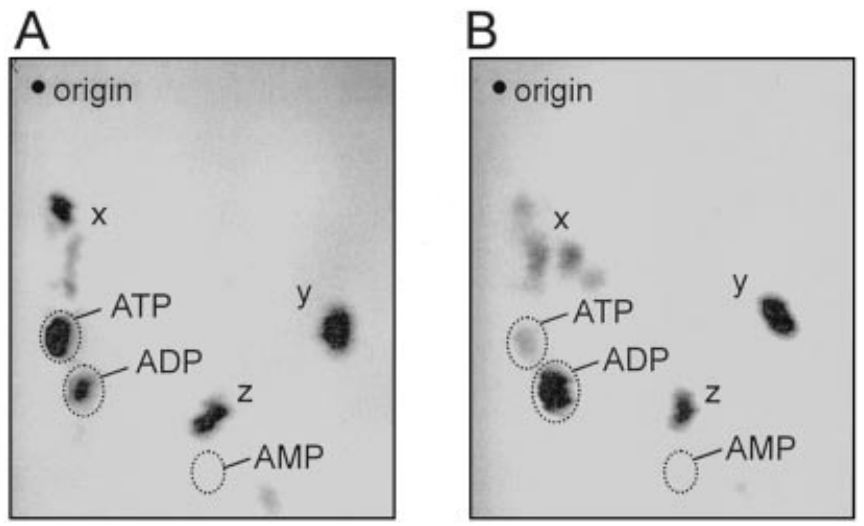

Figure 4 Quantification of ${ }^{32} \mathrm{P}$ in the $\gamma$-phospho group of ATP

Extracted nucleotides from lysates of ${ }^{32} \mathrm{P}$-radiolabelled $\mathrm{T}$-cells were separated by twodimensional paper chromatography either without further treatment $(\mathbf{A})$ or after treatment with hexokinase and glucose $(\mathbf{B})$. The results are representative of two separate experiments.

\section{Stoichiometry of $\boldsymbol{\beta}_{2}$ phosphorylation}

For the determination of the stoichiometry of $\beta_{2}$ phosphorylation it was necessary to determine the amount of radioactivity incorporated into the $\gamma$-phospho group of ATP. For this purpose we determined the saturation time of ATP synthesis in the ${ }^{32} \mathrm{P}-$ labelled T-cells (Figure 3). T-cells were labelled with $\left[{ }^{32} \mathrm{P}\right] \mathrm{P}_{\mathrm{i}}$ for different durations and ATP was quantified from TLC plates (Figure 3A). The incorporation of ${ }^{32} \mathrm{P}$ into ATP continued to increase after labelling for $10 \mathrm{~h}$; saturation of ATP with ${ }^{32} \mathrm{P}$ was achieved only after labelling overnight (Figure 3B). When twodimensional paper chromatography of the extracted nucleotides from T-cells labelled overnight with ${ }^{32} \mathrm{P}$ was performed (Figure $4 \mathrm{~A}$ ), it became evident that radioactivity was not incorporated into the $\alpha$-phospho group of ATP because there was no $\left[{ }^{32} \mathrm{P}\right] \mathrm{AMP}$ in the extracts. The migrations of ATP, ADP and AMP were verified by the addition of unlabelled standards. According to earlier chromatograms [37] the other spots represent $\mathrm{P}_{i}$ (indicated
Table 1 Determination of ${ }^{32} \mathrm{P}$ in ATP, ADP and ATP from radiolabelled Tcell lysates

The nucleotides extracted from ${ }^{32} \mathrm{P}$-labelled lysates were subjected to two-dimensional paper chromatography followed by liquid-scintillation counting. The results are representative of two separate experiments. The AMP was unlabelled and was identified by UV absorption on the chromatogram. The last column shows the radioactivity gained $(+)$ or lost $(-)$ relative to the control after treatment with hexokinase and glucose (see Figure 4).

\begin{tabular}{lrl}
\hline $\begin{array}{l}\text { Chromatographic } \\
\text { assignment } \\
\text { of spot }\end{array}$ & $\begin{array}{l}\text { Total radioactivity } \\
\text { in control (d.p.m.) }\end{array}$ & $\begin{array}{l}\text { Gain or loss } \\
\text { in radioactivity } \\
\text { (d.p.m.) }\end{array}$ \\
\hline ATP & 170644 & -156948 \\
ADP & 56944 & +82252 \\
AMP & 0 & - \\
\hline
\end{tabular}

by y), phosphatidylethanolamine (indicated by z) and GTP and GDP (in the region indicated by $\mathrm{x}$ ). When ${ }^{32} \mathrm{P}$-labelled T-cell lysates were treated with hexokinase and glucose (Figure 4B), the decrease in radioactivity in the ATP spot was $92 \% ; 52 \%$ of the radioactivity lost in the ATP spot was recovered in the spot for ADP (Table 1). Therefore the radioactivity of ATP from ${ }^{32} \mathrm{P}-$ labelled T-cells was present only in the $\beta$ - and $\gamma$-phospho groups, and in $1: 1$ proportion.

Table 2 lists the results of the stoichiometry measurements. In Expts. 1-3, T-cells were activated with PDBu; the stoichiometry of $\beta_{2}$ phosphorylation obtained was between 0.11 and 0.13 , yielding a mean stoichiometry of $0.12 \mathrm{~mol}$ of phosphate $/ \mathrm{mol}$ of $\beta_{2}$ subunit. The results obtained with $\mathrm{PDBu}$ activation alone were highly reproducible. In contrast, the stoichiometry of $\beta_{2}$ phosphorylation after pretreatment with okadaic acid and activation by $\mathrm{PDBu}$ gave more variation. The highest stoichiometry obtained was $1.25 \mathrm{~mol}$ of phosphate $/ \mathrm{mol}$ of $\beta_{2}$, probably reflecting efficient inhibition by okadaic acid. However, the lower stoichiometry $\left(0.62 \mathrm{~mol}\right.$ of phosphate $/ \mathrm{mol}$ of $\left.\beta_{2}\right)$ resulted from incomplete inhibition by okadaic acid, as was also observed in tryptic phosphopeptide maps of $\beta_{2}$ (Figure 1D). Thus a mean 


\section{Table 2 Stoichiometry of $\boldsymbol{\beta}_{2}$ phosphorylation}

${ }^{32}$ P-labelled T-cells were activated with either PDBu alone (Expts. 1-3) or with PDBu after pretreatment with okadaic acid (OA) (Expts. 4-7). The specific radioactivity of ATP was determined after extraction of nucleotides; the amount of $\beta_{2}$ subunit was determined after immunoprecipitation of the integrin and scanning. The stoichiometry of the $\beta_{2}$ phosphorylation was measured by comparing the incorporation of ${ }^{32} \mathrm{P}$ from the $\gamma$-phospho group of ATP into the $\beta_{2}$ subunit. The mean stoichiometric values were derived from separate experiments.

\begin{tabular}{|c|c|c|c|c|c|}
\hline \multirow[b]{2}{*}{ Experiment } & \multirow[b]{2}{*}{ Treatment } & \multicolumn{2}{|c|}{$\begin{array}{l}\text { Specific radioactivity } \\
\text { (d.p.m./pmol) }\end{array}$} & \multicolumn{2}{|c|}{ Stoichiometry of $\beta_{2}$ phosphorylation } \\
\hline & & ATP & $\beta_{2}$ & Values & Mean \pm S.D. \\
\hline 1 & PDBu & 170.2 & 10.9 & 0.13 & \\
\hline 2 & PDBu & 122.4 & 6.6 & 0.11 & \\
\hline 3 & PDBu & 122.4 & 6.9 & 0.11 & $0.12 \pm 0.01$ (Expts. 1-3) \\
\hline 4 & $\mathrm{OA}+\mathrm{PDBu}$ & 276.4 & 85.0 & 0.62 & \\
\hline 5 & $\mathrm{OA}+\mathrm{PDBu}$ & 86.1 & 53.9 & 1.25 & \\
\hline 6 & $\mathrm{OA}+\mathrm{PDBu}$ & 211.5 & 69.2 & 0.65 & \\
\hline 7 & $\mathrm{OA}+\mathrm{PDBu}$ & 120.4 & 69.3 & 1.15 & $0.92 \pm 0.32$ (Expts. $4-7)$ \\
\hline
\end{tabular}

stoichiometry of $0.92 \mathrm{~mol}$ of phosphate $/ \mathrm{mol}$ of $\beta_{2}$ subunit was obtained with a relatively high standard deviation.

\section{DISCUSSION}

The affinity and avidity of integrins for their ligands is often regulated in response to cytoplasmic signals generated by the stimulation of cellular receptors [2-5]. One possible mechanism underlying this 'inside-out' activation of integrins has been hypothesized to be the phosphorylation of integrin $\beta$ subunits. Different integrins have been shown to become phosphorylated on tyrosine residues [16-19] but because the tyrosine phosphorylation events are generally induced by ligand engagement, it is believed to mediate mainly 'outside-in' signal transduction by integrins. However, some integrins, namely $\beta_{2}$ [28-31] and $\beta_{3}$ [23], have been phosphorylated as a result of cytoplasmic signals after cellular activation. Phosphorylation of $\beta_{3}$ is believed to be involved in the affinity modulation of the platelet integrin $\alpha_{\mathrm{II}} \beta_{3}$ [42].

The phosphorylation state of $\beta_{2}$ leucocyte integrins has been reported to change in leucocytes activated by phorbol esters [28-31]. The $\alpha$ chain is constitutively phosphorylated in leucocytes, whereas the $\beta$ subunit becomes phosphorylated only after activation. The major phosphorylation site has been identified as $\operatorname{Ser}^{756}$ in the $\beta_{2}$ cytoplasmic domain [15] but the phosphorylation in this serine residue is believed not to be involved in the activation of $\beta_{2}$ integrin, because $\operatorname{Ser}^{756}$-mutated integrin is still activated by phorbol esters [15]. In the same study the mutation of the putative threonine phosphorylation sites (758-760) in $\beta_{2}$ caused a marked decrease in the adhesive function of leucocyte integrins; however, almost no phosphorylation was detected in threonine residues. A strong threonine phosphorylation of the $\beta_{2}$ subunit was then found by using the serine/ threonine phosphatase inhibitor okadaic acid [32]. This dynamic threonine phosphorylation of the $\beta_{2}$ subunit was observed in T-cells activated either by phorbol esters or by antibodies against the TCR complex but not in T-cells treated with okadaic acid alone, as has been reported to occur in neutrophils [43].

This study was designed to characterize further the phosphorylation events occurring in the $\beta_{2}$ integrins in T-cells after activation by phorbol ester. It was first of interest to identify the amino acids transiently phosphorylated in $\beta_{2}$. Tryptic phosphopeptide mappings of $\beta_{2}$ integrins were performed from ${ }^{32} \mathrm{P}$-labelled T-cells activated with either PDBu alone or with
PDBu after preincubation with okadaic acid. Activation by phorbol ester revealed a single phosphorylation site in $\mathrm{Ser}^{756}$, as observed earlier [15]. When the serine/threonine phosphatases were inhibited by okadaic acid before the activation, new phosphorylation sites were observed. Two of the threonine residues present in the $\beta_{2}$ cytoplasmic threonine triplet $\left(\mathrm{Thr}^{758}\right.$ $\mathrm{Thr}^{759}-\mathrm{Thr}^{760}$ ) were observed to become phosphorylated. Despite much effort it proved impossible to obtain a more specific identification of the threonine residues phosphorylated; this must await more sensitive analytical methods.

Earlier reports on the functional importance of the cytoplasmic threonine residues 758-760 of $\beta_{2}$ in the activation of the integrins [15] makes our finding of threonine phosphorylation in this triplet interesting. We found that phosphorylation takes place in two of the three threonine residues. Earlier it was shown that mutations in all three threonine residues were needed for a maximal decrease in adhesion. When threonine residues were mutated one by one, the inhibition of activation was only partial.

When the amino acid sequences in the different integrin $\beta$ subunit cytoplasmic domains involved in the phosphorylation of $\beta_{2}$ integrin are compared, striking similarities are observed. The $\beta_{1}$ subunit has a serine residue corresponding to $\operatorname{Ser}^{756}$ in $\beta_{2}$ as well as two threonine residues in the position where $\beta_{2}$ has three. The $\beta_{3}$ subunit lacks the serine residue in the position of $\operatorname{Ser}^{756}$ but has a Thr-Ser-Thr sequence corresponding the threonine triplet in $\beta_{2}$. Ser ${ }^{752}$ in the sequence of $\beta_{3}$ is important, because the point mutation $\operatorname{Ser}^{752} \rightarrow$ Pro results in Glanzmann's thrombasthenia [44]. However, the effect of the substitution of proline for the serine residue is likely to cause a conformational change in $\beta_{3}$ rather than to affect the phosphorylation of the residue [45]. In fact, the $\beta_{3}$ integrin was found to be phosphorylated mainly on threonine [23] and the phosphorylated threonine residue is assumed to be the C-terminal residue in the $\beta_{3}$ cytoplasmic tail [42]. The $\beta_{7}$ subunit shows the closest resemblance to $\beta_{2}$ integrin phosphorylation sites, having both a single serine residue in the position of $\operatorname{Ser}^{756}$ as well as a threonine triplet. The only difference is that the $\beta_{2}$ subunit has only one residue (alanine) between the serine and threonines, whereas $\beta_{7}$ has two residues (alanine and isoleucine). The similarity between the $\beta_{2}$ and $\beta_{7}$ sequences in this region is intriguing, because $\alpha_{4} \beta_{7}$, like $\beta_{2}$ integrins, is expressed only on leucocytes and the existence of leucocyte-specific signaltransduction elements are hypothesized to be involved in the activation of both $\beta_{2}$ and $\beta_{7}$ integrins [46]. A dynamic threonine phosphorylation might also be involved in $\beta_{7}$ activation. 
Even though the phosphorylation of $\beta_{2}$ integrins has been studied intensively, nothing has been known about the stoichiometry of the phosphorylation. Here we report that the phosphorylation of the $\beta_{2}$ subunit occurred in approx. $12 \%$ of the integrin molecules when T-cells were activated with phorbol esters; the phosphorylation took place at a single serine residue. When the phorbol ester-activated T-cells were preincubated with okadaic acid, the stoichiometry of the phosphorylation increased to $0.92 \mathrm{~mol}$ of phosphate $/ \mathrm{mol}$ of $\beta_{2}$ subunit. This phosphorylation occurred at three different sites, suggesting that the phosphorylation takes place in approx. $30 \%$ of the integrin molecules. However, because the dynamic phosphorylation events observed are highly affected by the incomplete inhibiton of phosphatases by okadaic acid, the phosphorylation might occur at one of the phosphorylation sites in $\beta_{2}$ more efficiently than in others.

Mechanisms by which an induced $\beta_{2}$ phosphorylation could regulate leucocyte adhesion are divided into two main possibilities: those resulting in an affinity change of individual integrin molecules, and those leading to an increased avidity of adhesion contacts through integrin clustering [47]. An affinity change of $\beta_{2}$ integrins has been reported in phorbol ester-activated T-cells in a small fraction of $\beta_{2}$ molecules [48], which correlates well with the relatively low stoichiometry of $\beta_{2}$ phosphorylation. However, recent studies indicate that neither phorbol esters nor TCR triggering could induce the high-affinity state of leucocyte integrins [49]. Rather, phorbol esters would increase the avidity of cellular contacts, probably through $\beta_{2}$ integrin clustering involving alterations in the cytoskeletal associations of the integrin complexes. It has previously been shown that dephosphorylation is important in $\beta_{2}$-integrin-mediated adhesion [50]. We consider that the phosphorylation/dephosphorylation reactions enable the integrins to 'walk' along the submembrane skeleton, thus forming integrin clusters and resulting in increased avidity. An involvement of $\beta_{2}$-integrin phosphorylation in the cytoskeletal association of the integrin complex has recently been postulated (L. Valmu, S. Fagerholm, H. Suila and C. G. Gahmberg, unpublished work).

We thank Leena Kuoppasalmi for skilful technical assistance, Yvonne Heinilä for secretarial help, Jussi Saarinen for the ESI mass spectrometer analyses, Pekka Kotovuori for the figures, and Kurt Fagerstedt for the use of the luminometer. This work was supported by the Academy of Finland, the Sigrid Jusélius Foundation, the Finnish Cancer Society, the Magnus Ehrnrooth Foundation and the Research and Science Foundation of Farmos Ltd. G.v.W. is a fellow of the Catharijne Foundation and is supported by the Dirk Zwager-Assink Foundation.

\section{REFERENCES}

1 Hynes, R. 0. (1987) Cell 48, 549-554

2 Springer, T. A. (1990) Nature (London) 346, 425-434

3 Gahmberg, C. G., Tolvanen, M. and Kotovuori, P. (1997) Eur. J. Biochem. 245 215-232

4 Ginsberg, M. H., Du, X. and Plow, E. F. (1992) Curr. Opin. Cell Biol. 4, 766-771

5 Kolanus, W. and Zeitlmann, L. (1998) Current Topics in Microbiology and Immunology, vol. 231 (Holzmann, B. and Wagner, H., eds.), pp. 33-49, SpringerVerlag, Berlin

6 Shimizu, Y., van Seventer, G. A., Horgan, K. J. and Shaw, S. (1990) Nature (London) 345, 250-253

7 Giancotti, F. G. (1997) Curr. Opin. Cell Biol. 9, 691-700

8 Laflamme, S. E., Homan, S. M., Bodeau, A. L. and Mastrangelo, A. M. (1997) Matrix Biol. 16, 153-163
9 Hughes, P. E., O'Toole, T. E., Ylänne, J., Shattil, S. J. and Ginsberg, M. H. (1995) J. Biol. Chem. 270, 12411-12417

10 Otey, C. A., Vasquez, G. B., Burridge, K. and Erickson, B. W. (1993) J. Biol. Chem. 268, 21193-21197

11 Lewis, J. M. and Schwartz, M. A. (1995) Mol. Biol. Cell 6, 151-160

12 Schaller, M. D., Otey, C. A., Hildebrand, J. D. and Parsons, J. T. (1995) J. Cell Biol. 130, 1181-1187

13 Shattil, S. J., O'Toole, T., Eigenthaler, M., Thon, V., Williams, M., Babior, B. M. and Ginsberg, M. H. (1995) J. Cell Biol. 131, 807-816

14 O'Toole, T. E., Ylänne, J. and Culley, B. M. (1995) J. Biol. Chem. 270, 8553-8558

15 Hibbs, M. L., Jakes, S., Stacker, S. A., Wallace, R. W. and Springer, T. A. (1991) J. Exp. Med. 174, 1227-1238

16 Johansson, M. W., Larsson, E., Lüning, B., Pasquale, E. B. and Ruoslahti, E. (1994) J. Cell Biol. 126, 1299-1309

17 Law, D. A., Nannizzi-Alaimo, L. and Phillips, D. R. (1996) J. Biol. Chem. 271, 10811-10815

18 Blystone, S. D., Lindberg, F. P., Williams, M. P., McHugh, K. P. and Brown, E. J. (1996) J. Biol. Chem. 271, 31458-31462

19 Mainiero, F., Pepe, A., Wary, K. K., Spinardi, L., Mohammadi, M., Schlessinger, J. and Giancotti, F. G. (1995) EMBO J. 14, 4470-4481

20 Patarroyo, M., Beatty, P. G., Fabre, J. W. and Gahmberg, C. G. (1985) Scand. J. Immunol. 22, 171-182

21 Rothlein, R. and Springer, T. A. (1986) J. Exp. Med. 163, 1132-1149

22 Shattil, S. J. and Brass, L. F. (1987) J. Biol. Chem. 262, 992-1000

23 Parise, L. V., Criss, A. B., Nannizzi, L. and Wardell, M. R. (1990) Blood 75, 2363-2368

24 Gahmberg, C. G., Valmu, L., Fagerholm, S., Kotovuori, P., Ihanus, E., Tian, L. and Pessa-Morikawa, T. (1998) Cell. Mol. Life Sci. 54, 549-555

25 Keizer, G. D., Visser, W., Vliem, M. and Figdor, C. G. (1988) J. Immunol. 140, 1393-1400

26 Landis, R. C., Bennett, R. I. and Hogg, N. (1993) J. Cell Biol. 120, 1519-1527

27 Dustin, M. L. and Springer, T. A. (1989) Nature (London) 341, 619-624

28 Hara, T. and Fu, S. M. (1986) in Leucocyte Typing II, vol. 3 (Reinherz, E. L., Haynes, B. F., Nadler, L. M. and Bernstein, I. D., eds.), pp. 77-84, Springer-Verlag, New York

29 Chatila, T. A., Geha, R. S. and Arnaout, M. A. (1989) J. Cell Biol. 109, 3435-3444

30 Buyon, J. P., Slade, S. G., Rebman, J., Abramson, S. B., Philips, M. R., Weissmann, G. and Winchester, R. (1990) J. Immunol. 144, 191-197

31 Valmu, L., Autero, M., Siljander, P., Patarroyo, M. and Gahmberg, C. G. (1991) Eur. J. Immunol. 21, 2857-2862

32 Valmu, L. and Gahmberg, C. G. (1995) J. Immunol. 155, 1175-1183

33 Nortamo, P., Patarroyo, M., Kantor, C., Suopanki, J. and Gahmberg, C. G. (1988) Scand. J. Immunol. 28, 537-546

34 Schneider, C., Newman, R. A., Sutherland, D. R., Asser, U. and Greaves, M. F. (1982) J. Biol. Chem. 257, 10766-10769

35 Laemmli, U. K. (1970) Nature (London) 227, 680-685

36 Hunter, T. and Sefton, B. M. (1980) Proc. Natl. Acad. Sci. U.S.A. 77, 1311-1315

37 Holmsen, H., Dangelmaier, C. A. and Akkerman, J.-W. N. (1983) Anal. Biochem. 131, 266-272

38 van Willigen, G., Hers, I., Gorter, G. and Akkerman, J.-W. N. (1996) Biochem. J. 314, 769-779

39 Holmsen, H., Storm, E. and Day, H. J. (1972) Anal. Biochem. 46, 489-501

40 Carr, S. A., Huddleston, M. J. and Annan, R. S. (1996) Anal. Biochem. 239, 180-192

41 Sullivan, S. and Wong, T. W. (1991) Anal. Biochem. 197, 65-68

42 van Willigen, G. and Akkerman, J.-W. N. (1997) Platelets 8, 225-234

43 Merrill, J. T., Winchester, R. J. and Buyon, J. P. (1994) Clin. Immunol. Immunopathol. 71, 216-222

44 Chen, Y.-P., Djaffar, I., Pidard, D., Steiner, B., Cieutat, A.-M., Caen, J. P. and Rosa, J.-P. (1992) Proc. Natl. Acad. Sci. U.S.A. 89, 10169-10173

45 Liu, X.-Y., Timmons, S., Lin, Y.-Z. and Hawiger, J. (1996) Proc. Natl. Acad. Sci. U.S.A. 93, 11819-11824

46 Lub, M., van Vliet, S., Oomen, S. P. M. A., Pieters, R. A., Robinson, M., Figdor, C. G. and van Kooyk, Y. (1997) Mol. Biol. Cell 8, 719-728

47 Stewart, M. and Hogg, N. (1996) J. Cell. Biochem. 61, 554-561

48 Lollo, B. A., Chan, K. W. H., Hanson, E. M., Moy, V. T. and Brian, A. A. (1993) J. Biol. Chem. 268, 21693-21700

49 Stewart, M. P., Cabanas, C. and Hogg, N. (1996) J. Immunol. 156, 1810-1817

50 Hedman, H. and Lundgren, E. (1992) J. Immunol. 149, 2295-2299

Received 13 November 1998/4 January 1999; accepted 20 January 1999 